\title{
The Concept of Time in "Enarrationes in Psalmos" by Saint Augustine
}

\author{
BOGDAN CZYŻEWSKI
}

Adam Mickiewicz University in Poznań

czybo@amu.edu.pl, ORCID: 0000-0002-6040-5523

\begin{abstract}
What is time? What is its nature, designation and aim? Saint Augustine attempted to resolve these and other questions in his greatest exegetical-homiletical work, Enarrationes in Psalmos. The Bishop of Hippo, commenting on particular verses of the Davidic Psalms, comes to the conviction that time is a variable and fragile value, just like the world and man, which are subject to its laws. The time created by God had a beginning, it abides, and it will have an end. However, this does not mean that the passing of time should be viewed only in a negative sense, for at a concrete moment in time the Son of God became incarnate in order to save man. Time also exists so that man has an opportunity to be converted and to enter eternity. For the Bishop of Hippo, there is no concept of time in eternity, which is changeless and lasts forever. In his conception of time, we can see not only its pure physical aspect, but above all, its theological dimensions. In particular, it contains a message for man that refers not only to the present, but predominantly to the future, to an eternity that inspires great optimism for all people.
\end{abstract}

Keywords: Augustine, psalms, time, eternity, man, passing

Enarrationes in Psalmos, ${ }^{1}$ St Augustine's greatest exegetical-homiletic work, is a collection of his homilies ${ }^{2}$ delivered in $392-410 .^{3}$ It constitutes a real mine of theological knowledge containing numerous diverse subjects that were presented and elucidated so that believers could get to know the spiritual richness and deep realities hidden in the Psalms. ${ }^{4}$

The category of time is one of the many issues that can be found in the Expositions on the Book of Psalms. St Augustine refers to it in several places, especially in those verses of the psalms that mention the passing of time, the shortness and

1 See Augustinus, Enarrationes in Psalmos (PL 36, 67-1028; 37, 1033-1968).

2 André Wilmart ("La tradition," 295-315) believes that the collection of St Augustine's commentaries on the psalms includes 86 dictated and 119 spoken texts.

3 Cf. Lancel, Saint Augustin, 741. Gustave Bardy (Święty Augustyn, 310) is of the opinion that Augustine began commenting on the first psalms just before the year 404. Authors writing on the chronology of psalms commented on by the Bishop of Hippo include, among others; Zarb, Chronologia Enarrationum, 253-256; Rondet, “Essais," 61 (1960) 111-127, 258-286; Rondet, “Essais," 65 (1964) 110-136; Rondeau, "Les Commentaires," 167-175; Tupaj, "Miłosierdzie Boże”, 116-121.

4 Cf. Corsato, Biblia w interpretacji Ojców Kościoła, 197. 
fragility of life on earth and also eternal life. Thanks to that, it is possible to interpret his views on the subject of time as well as to define and describe time, especially that the Bishop's interpretation was not limited to the literal sense; he tried to seek and explore the spiritual, moral and mythical sense in the biblical text. ${ }^{5}$

Studies on the subject of time in St Augustine's doctrine are certainly not marginal but aspire to be valuable and revealing. For their authors have explored time, its essence, nature, designation and purpose, as understood by the Bishop of Hippo, especially from the philosophical and psychological and partly the theological side. Yet, they had paid little attention to Enarrationes in Psalmos, focusing on analysing his Confessiones or De civitate Dei, or trying to study this theme in his other works. ${ }^{6}$ Therefore, it is worth taking up the challenge to look at his conception of time developed in this monumental work - Expositions on the Book of Psalms by the greatest Father of the Western Church. We are aware of the limitations imposed by a research paper, and also of the volume of the work in question, which is in no way comparable to the size of a paper, and consequently, of St Augustine's multitude of assertions on the subject of time. Having that in mind, our attempt will concern the most important ideas to obtain a picture of his doctrine on time elaborated in Enarrationes in Psalmos.

\section{Christ Was Born Outside Time and Within Time}

The first thesis that can be noticed in St Augustine's Enarrationes in Psalmos in relation to his considerations on time is connected with the Person of Christ. The Bishop of Hippo mentions his double birth. He distinguishes between the eternal birth of the Son from the Father and his birth within time, from the Virgin Mary. Analysing the meaning of the words from Ps 109:16 ("From the womb before the morning star I begot you"), our author writes on the subject of the first birth:

Do not ask when (quando), because "when" has no meaning in eternity (aeternitas non habet quando). "When" and "sometimes" (quando et aliquando) are notions that belong

5 On the subject of St Augustine's biblical exegesis, especially the one he used in Enarrationes in Psalmos, see Simonetti, Między dosłownością a alegorią, 357-360. For the Bishop’s biblical exegesis see Bonnardière, L'initiation biblique d’Augustin, 27-47; Wielgus, Badania nad Biblia w starożytności i w średniowieczu, 64-66.

6 A few bibliographical suggestions for this topic are: Weinand, Augustinus erkenntniskritische Theorie der Zeit; Guitton, Le temps et l' éternité; Marrou, Lambivalence du temps; Berlinger, "Zeit und Zeitlichkeit," 493-510; Chaix-Ruy, "La Cité de Dieu," 923-931; Boros, "Les catégories de la temporalité," 323-358; Lampey, Das Zeitproblem; Lechner, Idee und Zeit; Quinn, "The Concept of Time," 5-57; Duchrow, "Der sogenannte psychologische Zeitbegriff Augustins," 267-288; Kaiser, Augustinus. Zeit und «Memoria»; Janich, „Augustins Zeitparadox”, 168-186; Schmidt, Zeit und Geschichte bei Augustin. 
to time. He through whom time was created was not born from the Father within time (de Patre non est natus in tempore, per quem facta sunt tempora).?

The Bishop of Hippo reckons that the birth of the Son of God took place before all times since in his idea of eternity, we do not deal with the concept of time. It would even be illogical, inappropriate or even absurd to attribute time to the One who created it. Augustine intentionally emphasises the fact that time is one of the realities that owe their existence to the Creator. Reflecting on the birth of Christ from the Father, he indicates that it should not be seen in human terms. He firmly rejects such a premise of this mystery of faith. He says that in relation to the birth of the Son from the Father "let us not make the mistake of thinking that the psalm refers to his human birth (nativitas humana), but raise our minds to his eternal generation (aeternitas divina)." Christ did not come into existence when he was born from Mary as "Christ was born before all times (ante tempora invenias natum esse Christum)." Thus "he cannot be thought to have been born from any point in time (non potest videri natus ex tempore), because all times themselves are creatures of God (tempora creatura Dei sunt)." ${ }^{\prime 0}$ According to Augustine, time may be said to come from the hands of God; $\mathrm{He}$ is its Creator and Lord. ${ }^{11}$

Speaking of Christ being born from the Father, St Augustine clearly emphasises his eternality and at the same time his superiority over all creatures. In his opinion, this proves that Christ has always existed as God and that he exists outside any concept of time. For Christ

is God, not only before Abraham (ante Abraham), but before the creation of heaven and earth (ante coelum et terram) [...], not only before Abraham, but before Adam (ante Adam); and not only before Adam, but before all the angels (ante omnes angelos), and before heaven and earth (ante coelum et terram), because all things were made through him (omnia per Ipsum facta sunt). ${ }^{12}$

Therefore, the category of time can in no way be referred to the eternal existence of the Son of God, even considering that he participated in the work of the entire creation. The Bishop of Hippo's statements are not only limited to explaining the birth of Christ from the Father, but also concern his second birth, that is to say, being born as a human. Although speaking of the incarnation of the Son of God, he does

\footnotetext{
Augustinus, Enarrationes in Psalmos 109,16 (WSA 19, 279).

Augustinus, Enarrationes in Psalmos 92,6 (WSA 18, 368).

Augustinus, Enarrationes in Psalmos 92,6 (WSA 18, 367).

Augustinus, Enarrationes in Psalmos 92,6 (WSA 18, 367).

Cf. Edling, "Czas i historia," 77.

Augustinus, Enarrationes in Psalmos 92,6 (WSA 18, 368).
} 
not always use the term "time" (tempus), ${ }^{13}$ the context of his statement may lead us to conclude that the human birth of Christ was done within time since he was born of Mary, who, like every human being, was subjected to the laws of time. Hence Augustine says:

A virgin descended from David's flesh (ducens propaginem de carne David) gave birth to Christ from her womb (ex illo utero natus Christus), and so it could be said that he was born from the womb of David. From the womb untouched by any male (ex utero, quo masculus non accessit)..$^{14}$

Existing eternally outside all times, through the assumption of the human nature, Christ entered the earthly time of living. ${ }^{15}$ Apart from the aforementioned assertion, it is worth to emphasise another important aspect the author of Expositions on the Book of Psalms indicates. Not only does he note Christ's true humanity, but also shows Mary's virginity stressing that Christ's conception was done without a male's participation.

Further, the Bishop of Hippo justifies why Christ came into the world. He was born in flesh as a human for our sake. It was a human birth that took place within time and had its purpose. Here God made use of time sending his Son into the world in a human body and with a specific plan for man. This illustrates to St Augustine that it was "time for the Lord to act," 16 which meant

the time when the law had been fragmented (tempus fuit) was therefore the time for the mercy of God to be sent to us through the only-begotten Son (misericordia mitteretur). The law sneaked in that sin might abound. By sin the law was broken to pieces, and so at this most opportune time Christ came (opportuno iam tempore Christus advenit), so that where sin abounded, grace might abound even more (Rom 5:20). ${ }^{17}$

So time began to exist for the sake of salvation through Christ who reconciled man with the Father. Augustine, speaking of offense (delictum), meaning sin, pays attention to the Law (Lex), in the light of which the devastating effects of evil committed by man could be seen. Thus the coming of the Son of God in a human body

13 We do not provide all of the terms used by Augustine in order to describe time and history. In the text of the article, especially in the quotations, we use Latin terminology in order to show the diversity of terms, with the use of which, the bishop of Hippo explains the concept of time in Enarrationes in Psalmos.

14 Augustinus, Enarrationes in Psalmos 109,16 (WSA 19, 279).

15 Cf. Edling, "Rewelatywno-temporalny wymiar Odkupienia," 233.

16 Cf. Augustinus, Enarrationes in Psalmos 118(26),7 (WSA 19, 469).

17 Augustinus, Enarrationes in Psalmos 118(26),7 (WSA 19, 469). 
at a specific moment in time became an expression of God's mercy and at the same time God's grace thanks to which man's offense was overcome.

Summarising our deliberations, it should be stated that St Augustine considered the issue of time in a twofold perspective. First, there is no concept of time. Eternity has no time as evidenced by the birth of God's Son from the Father. He was born before all times, and with all certainty, it was not a birth in the human sense. His second birth took place when he, the Son of God, was made flesh, i.e. he took the body from the Virgin Mary. In this perspective, we can speak of the earthly dimension of time, in which the Son of God came into the world. This point of time was needed by humanity so that man's salvation could be accomplished. These considerations of the Bishop of Hippo allow us to conclude that his explication of the origin of time does not follow a "temporal order" but rather a causal order.

\section{The Passing of Time}

The second idea connected with time that can be found in St Augustine's Expositions on the Book of Psalms concerns time as something difficult to define and capture, namely the passing of time in our world. This time is impermanent and so is everything that is created within the earthly time. The Bishop of Hippo emphasises this truth especially when he focuses on the eternal. He reminds us of the fact that we cannot stop time - it flies like everything that becomes man's needless and pointless concern. Referring to Ps 30:12 ("You hated those who cling to worthless idols"), he means all those who forget the passing of time and amass earthy goods that cannot be used in any way in eternity. He warns us:

If you put your trust in money, you are paying futile regard to vain things (observas vanitatem); if you put your trust in high office or some exalted rank in human government, you are paying futile regard to vain things. When you put your trust in all these, either you expire, and leave them all behind (tu exspiras, et ea hic dimittis), or they will crumble while you are still alive (omnia pereunt), and what you trusted will have let you down (in spe tua deficis). ${ }^{18}$

It should be noted that the theme of passing time reappears St Augustine's reflections, which is utterly understandable when we take into account the recurring verses of the psalms that address these issues, for example the words of Psalm 38:12: "Show me, o Lord, my end and the measure of my days." St Augustine uses them to make listeners aware that every moment, and all that happens in it, passes by quickly,

18 Augustinus, Enarrationes in Psalmos 30(2),12 (WSA 15, 331). 
which is exemplified by ageing. However, not everyone is capable of perceiving these changes, and especially the process of the passing of time:

You are not; for even today (ipsum hodie), from the point when we began speaking until the present moment (usque ad hoc momentum), you know we have grown older (sentis quia senuimus). You cannot see your hair growing, yet even now as you stand here, or while you are busy with some work, or talking, your hair is growing. It does not grow suddenly, so as to send you scurrying for a barber. Our lifetime is flying past (aetas transvolans), for those who understand, and for those who take no notice, and for those intent on evil designs. ${ }^{19}$

The passing of time may also be noticed when we acknowledge that in this world nothing is eternal: neither years, nor months, nor days and moments. None of them will remain. Therefore, referring to time we must use extremely precise words, although this is not entirely possible. For when we use the term "this year" (hoc anno), we realise that we have nothing of it "except one day in which we live (praeter unum diem in quo sumus)." ${ }^{20}$ On the other hand, saying "today" (hodie), we should know that "the early morning hours have already past (horae matutinae iam transierunt), while the later hours have not yet arrived (horae futurae nondum venerunt)." ${ }^{21}$ Thus, thinking of today, we should not speak of "at this hour" (hodie horae), but "at this moment (hoc momento),"22 which, according to the Bishop of Hippo, is not right, either, because just uttering the word "moment" (momentum) conveys the passing time: "it is gone even while I am pronouncing its syllables! Look: two syllables, "mo-ment." The second is not audible (altera non sonat) until the first has died away (nisi cum illa transierit)." ${ }^{23}$ The same may be said about a single syllable: "even if we take a single syllable, a syllable composed of two letters, the second letter cannot make itself heard (non sonat posterior littera) until the first has faded (nisi prior abierit)." ${ }^{\prime 24}$ All that testifies to the passing of time because our earthly years are changeable. Hence, "I thought about (anni aeterni cogitandi sunt) bygone days (anni qui stant), and called to mind the years of eternity (non venientibus et abeuntibus diebus peraguntur). ${ }^{25} \mathrm{At}$ this point, Augustine departs from the thesis about the eternity of the world, propagated by the ancient Greek philosophy, Aristotle and Plato, regarding it as incompatible with the Christian thought. Time can be said to belong to God and he uses it to show its temporariness and fugitiveness. ${ }^{26}$

\footnotetext{
19 Augustinus, Enarrationes in Psalmos 38,12 (WSA 16, 182).

20 Augustinus, Enarrationes in Psalmos 76,8 (WSA 18, 80).

21 Augustinus, Enarrationes in Psalmos 76,8 (WSA 18, 80).

22 Augustinus, Enarrationes in Psalmos 76,8 (WSA 18, 80).

23 Augustinus, Enarrationes in Psalmos 76,8 (WSA 18, 80).

24 Augustinus, Enarrationes in Psalmos 76,8 (WSA 18, 80).

25 Augustinus, Enarrationes in Psalmos 76,8 (WSA 18, 80).

26 Cf. Edling, "Czas i historia," 79.
} 
Exploring the passing of time, St Augustine does not focus only on man and his works who are subject to temporality. He says the same about nature, the whole world that surrounds us: "rapacious time rolls on (temporum rapacitas volvitur); creatures are time-bound (temporalibus) and mortal (mortalibus). ${ }^{27}$ In his opinion, this is not an accidental phenomenon, but one that is intended by God, who on the one hand testifies to the admirable beauty of the world he created, and on the other, to its inevitable transitoriness. These truths are some kind of lesson for humans so that they become aware of their earthly situation: they, just like time, are transient and impermanent. $^{28}$

Moreover, St Augustine often treats time as vanity since time flies. Everything that is "transitory is rightly called vanity. It fades away with time (evanescit enim per tempus), like smoke wafted off by the breeze (tamquam in auras fumus)." ${ }^{29} \mathrm{He}$ is entitled to such an opinion by comparing time to what can be described as eternity. ${ }^{30}$

According to Augustine, time, i.e. that which is temporal, is transient and impermanent. In addition, "all those things which are to be closed down at the end of time (omnia quae temporis fine clauduntur) are to be regarded as business already finished (pro transactis)." ${ }^{31}$ Adequately, time has a three-phase structure: a beginning, a course, i.e. duration, and it will also have an end. So we should look to the future, just like St Paul did by "forgetting what was behind his back, which we can take to mean temporal matters, and stretching out toward those ahead in his eagerness for what is eternal (cf. Phil 3:13)."32 St Augustine also mentions those who "have presumptuously claimed to know all about times (praesumere scientiam temporum)." ${ }^{33}$ We cannot play with "the uncertainty of time (temporum incerto) by the comparison, like a watch in the night," 34 meaning something short because a thousand years in the Lord's sight are like a day that has just gone by (cf. Ps 89:5). ${ }^{35}$

Also, Ps 102:22 ("As for human beings, their days are like grass; they shall bloom like a flower of the field") testifies to the shortness of time. The comparison of human life to grass and to a beautifully blooming flower is undeniably correct. Similarly, in nature, both grass and flowers, even though beautiful, are not eternal; soon they wither away and so do human beings. Their lives on earth will pass away, which, however, does not mean their total annihilation. God allows us to live on earth for a certain period of time. Although we will die and end our earthly time, we will cross

\footnotetext{
Augustinus, Enarrationes in Psalmos 118(27), 1 (WSA 19, 471).

Cf. Augustinus, Enarrationes in Psalmos 118(27),1.

Augustinus, Enarrationes in Psalmos 143,11 (WSA 20, 431).

Cf. Augustinus, Enarrationes in Psalmos 143,11.

Augustinus, Enarrationes in Psalmos 89,5 (WSA 18, 305).

Augustinus, Enarrationes in Psalmos 89,5 (WSA 18, 305).

Augustinus, Enarrationes in Psalmos 89,5 (WSA 18, 306).

Augustinus, Enarrationes in Psalmos 89,5 (WSA 18, 306).

Cf. Augustinus, Enarrationes in Psalmos 89,5.
} 
over into eternity, which we owe to the Father who taking into account the fragility of human life

sent his Word to us. He made his eternally abiding Word (manet in aeternum) a brother to that grass (non manet in aeternum). He caused the Word, who is his only-begotten Son by nature, his only Son born from his own substance, to become the brother of a multitude of adopted brothers and sisters. Do not be amazed to hear that you will share in his eternity (aeternitatis illius). ${ }^{36}$

The Bishop of Hippo uses yet another comparison to show the shortness of time and man's transitoriness in time. He refers to the moon since it "at first is new born, then waxes, and comes to the full, grows old, and dies," ${ }^{37}$ perceiving the moon as a symbol of nothingness, corporality and human mortal condition. ${ }^{38}$ Despite their mortality, human beings head towards immortality. Augustine explains this truth on the example of the city of Jericho and the biblical narrative about a man who was attacked by robbers and then encountered a good Samaritan (cf. Luke 10:30-37). He says:

The moon is used in scripture as an image of the mutability of our mortal condition (pro mutabilitate huius mortalitatis ponitur); and that is why the man who fell among robbers is pictured as going down from Jerusalem to Jericho, for the Hebrew name for that town, Jericho, is said to mean "the moon." The traveler was thus descending from immortality to mortality (ab immortalitate ad mortalitatem). ${ }^{39}$

Therefore, the symbolism of the moon in its changing phases should direct man's thought to the truth about resurrection. The moon's disappearance and appearance to show the fullness of light is the proof of the possibility of further existence. ${ }^{40}$ However, Augustine realises that his analogy contains a certain imperfection since the moon, on the one hand, testifies to mortality, and on the other hand, to immortality. For that reason, we must not forget that the moon changes as the result of its consecutive phases during the different months, while the resurrection of Christ took place once and for all times. ${ }^{41}$ Unlike the cyclical conception of time and history promoted by Greek philosophy, St Augustine deals with a linear conception of time directed towards eternity. It states that even though time has its beginning and end, all things are ultimately directed towards immortality. ${ }^{42}$

\footnotetext{
36 Augustinus, Enarrationes in Psalmos 102,22 (WSA 19, 102-103).

37 Augustinus, Enarrationes in Psalmos 60,8 (WSA 17, 199).

38 Cf. Zgraja, "Symbolika księżyca," 747.

39 Augustinus, Enarrationes in Psalmos 60,8 (WSA 17, 199).

40 Cf. Augustinus, Enarrationes in Psalmos 102,9.

41 Cf. Zgraja, "Symbolika księżyca," 750; Sawicka, "Symbolika lunarna," 14.

42 Cf. Hubaux, Saint Augustin et la crise cyclique, 943-950.
} 
The assertions quoted so far show that St Augustine approached the category of time in a rather sceptical or even rational way. He does not seem to be encouraging us to spend time living our lives to the full. On the contrary, he tried to convince us that time flies and runs out quickly; it is not a permanent value, and the passing of time reminds us of the end of our lives and that our lives and works are we temporary.

\section{Time and Eternity}

The third thesis related to time undertaken by St Augustine in his Expositions on the Book of Psalms may be called a reflection on what is temporal and what is eternal. Speaking about the present moment, i.e. temporality, he states that the time "from Adam to the end of the world (in finem saeculi) - is but a tiny drop (exigua gutta) compared with eternity (est comparata aeternitati)."43 For it has its end and is short, especially when eternity is taken into account. St Augustine is very critical about temporality. We can even say that he speaks about it with contempt. He advises us to despise temporal things as they may be obstacles to entering what we call eternity. Moreover, he even uses an interesting analogy to discourage us from enjoying our earthly lives: "If you find satisfaction in this present life, you are pressing your ear to the ground; if you seek satisfaction in your past experiences, even as they slide away beneath you, you have blocked your other ear with your tail." ${ }^{44}$ Here Augustine illustratively refers to the behaviour of a snake that, being extremely cunning, plugs its ears in such a way that it sticks one ear to the ground, while covering the other with its tail not to listen to the charmer's voice and not to take his medicine in the form of his healing voice. For him it was the Donatists who behaved like snakes being deaf to any voice; they put their fingers in their ears and did not listen to the voice of the true Church. ${ }^{45}$ This image, obviously, refers to the way man treats earthly things and eternal things. Augustine explains that the tail should be interpreted as the past things. We should take them off and should not adhere to this present time, but listen and look to what have been promised to us, i.e. eternal life. ${ }^{46}$ So for Augustine, time is a reality that has a historical dimension; it has its past and present. Yet, its end will surely come.

Further, Augustine advises us not to spend time on accumulating temporal goods for the sake of our children ensuring prosperous lives to them since their lives, like their parents' lives, will end one day. The most important thing is their future, eternal

\footnotetext{
Augustinus, Enarrationes in Psalmos 101(2),9 (WSA 19, 70).

Augustinus, Enarrationes in Psalmos 57,10 (WSA 17, 131-132).

Cf. Augustinus, Enarrationes in Psalmos 57,9.

Cf. Augustinus, Enarrationes in Psalmos 57,10.
} 
lives, which he calls "treasure." Thus parents' care should not focus on what is temporal but on what will last forever. Amassing and storing goods should be related to eternal life so that parents can ensure it to themselves and their children. ${ }^{47}$

As already emphasised, reflecting on the present day Augustine draws his attention to its shortness and fragility comparing it to what is eternal: "this time that seems to us so long, is really no more than a moment (punctum). Anything that has an end is not long (non est diu quod habet extremum)." ${ }^{38}$ Man, now and then thinking about the beginning of the world and remembering Adam, comes to the conclusion that both are distant. However, we must not forget that the time in which the world exists, though seemingly long, passes by and "is very brief in God's eyes (in oculis Dei breve est)." ${ }^{49}$

Commenting on Ps 36:10, St Augustine re-examines the false impression concerning the length of time. He ponders over the meaning of the verse: "A little while yet, and the sinner will not be there." Observing that many centuries passed by from Adam to the present day, we must cherish the hope that "the future time that still remains will speed by (sic pauca quae restant, utique transibunt)." ${ }^{50}$ So Augustine encourages us to note the speed of the passing of time and look to eternity for which we should be prepared because "in the same state that you depart from this life you will be delivered to the life beyond (qualis enim exieris de hac vita, talis redderis illi vitae)." ${ }^{51}$ This statement introduces us to yet another important theme related to the Augustinian concept of time.

Time should not be considered only from a negative perspective. Augustine perceives its positive aspect - time is a gift of God's mercy. This thesis has already been discussed while explicating Augustine's idea related to the incarnation of Christ, which was completed at a specific moment in time and which had its own objective. Here, Augustine elaborates on this subject presenting time as a value that serves humanity; time whose existence was causal. God gives man time so that he can hear his words and do appropriate penance for his sins. That is why our author encourages us to use the present day in a proper and fruitful way. For God "grants mercy" 52 in earthly life and applies the principle of mercy towards people. On the other hand, there will only be judgment in eternal life, and "God's justice will in no way call back for them the chance they have thrown away by their own injustice." 53 At this point, Augustine gives his understanding of mercy and justice. Mercy can always be experienced in earthly life, while God's justice will be applied in our future life.

\footnotetext{
47 Cf. Augustinus, Enarrationes in Psalmos 38,12.

48 Augustinus, Enarrationes in Psalmos 30(2),8 (WSA 15, 327).

49 Augustinus, Enarrationes in Psalmos 30(2),8 (WSA 15, 327).

50 Augustinus, Enarrationes in Psalmos 36(1), 10 (WSA 16, 99).

51 Augustinus, Enarrationes in Psalmos 36(1),10 (WSA 16, 99).

52 Augustinus, Enarrationes in Psalmos 36(1),2 (WSA 16, 93).

53 Augustinus, Enarrationes in Psalmos 36(1),2 (WSA 16, 93).
} 
Does this mean that after death, on the day of judgment, mankind cannot count on God's mercy? Augustine does not say this; on the contrary, he views both matters in chronological categories. Commenting on Ps 32:10, he says that "this present time is the season of mercy (tempus misericordiae), but then will be the season for judgment (tempus iudicii)." ${ }^{54}$ Yet, saying that he does not deprive man of hope since in many points, he stresses some kind of balance between mercy and justice, always focusing on the greatness of God's mercy which surpasses his justice. But here Augustine specifies a condition that this truth refers to those who asked for mercy and showed mercy to others during their earthly lives. ${ }^{55}$

Reflecting on eternity, Augustine warns us not to perceive it in the manner of earthly time. Pondering on the expression included in Ps 90:12 ("I will fill him completely with the length of days") he explains that "the length of days" (longitudo dierum) should be understood as eternal life (vita aeterna). It is not about length or shortness in the sense that winter days are short, while summer days are long. Eternity designates "length that has no end (longitudo quae non habet finem)." ${ }^{56}$ In addition, eternity should become every man's desire. Augustine even dares to say that "if we are greedy, we should be greedy for eternal life (vitae aeternae debemus esse avari). Yearn for the life that has no end (non habet finem). That is where our greed should stretch." ${ }^{57}$

A definition of eternity can also be found in Expositions. Referring to Jeremiah's prophecy of rebuilding the city of Jerusalem (cf. Jer 25:12; 29:10), he states that through this oracle God wants to show us "everything necessary to perfect the earthly image of our city (totum explicaretur quod ad persolvendam imaginem pertinebat)." 58 The city symbolises a dwelling place in which "there is no revolving time, because no one who dwells there declines or grows old." ${ }^{9}$ Therefore, one cannot speak of eternity as a certain time since time refers to what is temporal. Time was needed so that "all the development that occurred in time (fiebant secundum tempus), through material changes and human activity, were sins and foreshadowings of things to come (signa erant et praenuntiationes futurorum)." ${ }^{\prime 0}$ Consequently, for Augustine, there exists a distinct difference between time and eternity: time does not exist without successive changes, whereas there are no changes in eternity.

54 Augustinus, Enarrationes in Psalmos 32(2),10 (WSA 15, 403).

55 Cf. Augustinus, Enarrationes in Psalmos 32(2),11: "Ergo habet et iudicium in ipsa misericordia. Rursus in illo iudicio habebit et misericordiam, in eos utique quibus dicturus est: «Esurivi, et dedistis mihi manducare» (Mt 25:35)"; Ps 143:8; Ps 50:7. Cf. also Czyżewski, "Być miłosiernym jak Ojciec," 77-79 and Tupaj, "Miłosierdzie Boże," 143-144. On the subject of the relation between mercy and justice, not only in St Augustine’s work, cf. Mejzner, "Miłosierdzie i/a sprawiedliwość Boga," 41-64.

56 Augustinus, Enarrationes in Psalmos 90(2),12 (WSA 18, 343).

57 Augustinus, Enarrationes in Psalmos 90(2),12 (WSA 18, 343).

58 Augustinus, Enarrationes in Psalmos 147,5 (WSA 20, 524-525).

59 Augustinus, Enarrationes in Psalmos 147,5 (WSA 20, 525).

60 Augustinus, Enarrationes in Psalmos 147,5 (WSA 20, 524-525). 
At times, St Augustine faces helplessness attempting to fathom the mystery of eternity. He states that whatever could be said about it, it would always be insufficient as eternity cannot be expressed by words: "whatever you say will fall short of the reality." ${ }^{61}$ This does not mean that we should give up and stop speaking about it - in the end, eternity is our future. ${ }^{62}$ In his expositions to the psalms referring to time, Augustine constantly urges us to remember that all things on earth "flow past in the swift flux of time (temporis volubilitate), things that have no being other than "will be" and "has been" (erit et fuit)." ${ }^{63}$ On the contrary, in God's nature "there will not be anything which does not yet exist, or anything that was, which is not now; there is only that which is, and that is eternity itself (ipsa est aeternitas)." ${ }^{44}$ Therefore, man should not dwell upon this present time and the things it brings, but he should turn to "the eternal hope (ad aeternam spem conferant)," ${ }^{65}$ namely to God. In eternity, "all things stand, and nothing passes away (omnia stant, ubi nihil transit)." ${ }^{66}$ When man enters eternity, he will also stand and will not pass away. ${ }^{67}$

All things on earth, including man, came into existence in time or together with time. But as St Augustine says, God differs from what was created, "for God does not exist from any age (est ante saecula), but before the ages, nor does he live unto any age which reaches its end, for he is without end (sit ille sine fine)." ${ }^{68}$ The essence of God is unchangeable in every respect. For "there is no 'was' or 'will be' (Fuit, et Erit) in God, but only 'is' (Est)." ${ }^{69}$ Thanks to that, man shares this unchangeable essence of God. St Augustine says, "Such is the eternity which has become for us a refuge, so that we may flee to it from our changeable, time-bound condition, knowing that there shall abide (ecce quae aeternitas facta est nobis refugium, ut in ea mansuri, ad eam de hac temporis mutabilitate fugiamus)." ${ }^{\prime 70}$ As already mentioned, in the Bishop's opinion, time has a beginning and it will also have an end. Thus there is a significant difference between time that is changeable and eternity that is not subject to this law. ${ }^{71}$

Taking up the subject connected with eternity, St Augustine resorts to yet another analogy, speaking of man as an outer and inner being. For him, an outer being is the old self, like the Old Testament, that is exposed to time on earth and struggles with all sorts of adversities. He describes it more precisely

\footnotetext{
61 Augustinus, Enarrationes in Psalmos 60,8 (WSA 17, 199).

62 Cf. Augustinus, Enarrationes in Psalmos 60,8.

63 Augustinus, Enarrationes in Psalmos 9,11 (WSA 15, 147).

64 Augustinus, Enarrationes in Psalmos 9,11 (WSA 15, 147).

65 Augustinus, Enarrationes in Psalmos 9,11 (WSA 15, 147).

66 Augustinus, Enarrationes in Psalmos 121,6 (WSA 20, 9).

67 Cf. Augustinus, Enarrationes in Psalmos 121,6.

68 Augustinus, Enarrationes in Psalmos 89,3 (WSA 18, 304).

69 Augustinus, Enarrationes in Psalmos 89,3 (WSA 18, 304-305).

70 Augustinus, Enarrationes in Psalmos 89,3 (WSA 18, 305).

71 Cf. Lampey, Das Zeitproblem, 39-46.
} 
as we regard our sin, our mortality, our fleeting season (ad aetates succedentes), our groaning and toil and sweat, the stages of our life that succeed one another and will not stand still, but slip by imperceptibility from infancy to old age as we regard all these, let us see in them the old self (videamus hic veterem hominem), the old day (veterem diem), the old song (vetus canticum), the Old Covenant (Vetus Testamentum). ${ }^{72}$

Yet, there is hope, a new self, that is to say, the New Covenant, because "when we turn to our inner being (conversi autem ad interiorem), to all that is destined to be renewed in us (ad ea quae innovanda sunt) and replace the things subject to change (pro his quae immutabuntur), let us find there the new self (inveniamus hominem novum), the new day (diem novum), the new song (canticum novum), the New Covenant (Testamentum Novum)." ${ }^{3}$ This hope is that we move from the old to the new days, from that which is external to that which is internal, from time to eternity. ${ }^{74} \mathrm{Au}-$ gustine does not stop at this comparison but also points out that as it is with time that moves from changeability to stability, so is with us "as the old things decay (corrumpuntur exteriora) and the inner are made new (innovantur interiora)." 75 That which is external decays, "and meets its death (veniat in mortem), though it too will be renewed (renovetur) at the resurrection (in resurrectione)." 76 This process, although we are subject to the temporal, begins on earth "as we run our race [...], you further the process now as you strip yourself of the old (veteribus te exuendo), and run toward the new (in nova currendo)." 77 In the new reality, "the cosmic time" that God uses to reveal himself to man on earth "will turn into a never-ending eternity." ${ }^{78}$ At that moment there will be an end of all time, and its sense, aim and designation will be fulfilled since the eternal plan of God's salvation will be completed. ${ }^{79}$

Two basic questions can be found in St Augustine's assertions related to time. The first one refers to the perception of time that can be called "earthly" or "temporal." For the Bishop of Hippo, this time is predominantly impermanent, fragile and fugitive. It indicates the passing of time, which can be observed in the passing years, months, days and moments. The time given to man on earth is changeable and has a historic dimension; so we can perceive it linearly - it was created by God, it stands and is coming to an end. Nevertheless, St Augustine does not perceive this time only

\footnotetext{
Augustinus, Enarrationes in Psalmos 38,9 (WSA 16, 179).

Augustinus, Enarrationes in Psalmos 38,9 (WSA 16, 179).

Cf. Augustinus, Enarrationes in Psalmos 38,9.

Augustinus, Enarrationes in Psalmos 38,9 (WSA 16, 179).

Augustinus, Enarrationes in Psalmos 38,9 (WSA 16, 179).

Augustinus, Enarrationes in Psalmos 38,9 (WSA 16, 179).

Edling, "Rewelatywno-temporalny wymiar Odkupienia," 248.

Cf. Edling, "Czas i historia," 94.
} 
in negative categories but also sees the need for the time that God gives us. It is this time in which the Son of God who was made flesh came. And it should be looked at through the perspective of what will come. God gave it to man so that he can use it for his personal conversion, doing good and preparing himself for a life in eternity. Therefore, we can speak of the Augustinian concept of time not in the sense of the temporal order but rather of the causal order.

Moreover, the Bishop of Hippo discusses at length what we refer to as eternity. As it has no sense of time, Christ was born from the Father before all times. For man eternity is the most important good. Eternity is also radically different from the earthly time. Since nothing ends in eternity, but all things last there forever. According to Augustine, eternity is a constant concept that does not have its end. Although man is subject to changes on earth, and so is time, he will achieve permanence in eternity because he will rise to experience eternal life. Just like with time, we notice the transition from changeability to constancy, from temporariness to eternity, so will it be with man. He will pass from mortality to immortality and from what is perishable to what is permanent and imperishable.

\section{Bibliography}

\section{Sources}

Augustinus, Enarrationes in Psalmos (PL 36, 67-1028; 37,1033-1968); English trans. M. Boulding: Expositions of the Psalms 1-32 (ed. J.E. Rotelle) (The Works of Saint Augustine. A Translation for the 21st Century [=WSA] 3/15; Hyde Park, NY: New City Press 2000). 33-50 (ed. J.E. Rotelle) (WSA 3/16; Hyde Park, NY: New City Press 2000). 51-72 (ed. J.E. Rotelle) (WSA 3/17; Hyde Park, NY: New City Press 2001). 73-98 (ed. J.E. Rotelle) (WSA 3/18; Hyde Park, NY: New City Press 2002). 99-120 (ed. B. Ramsey) (WSA 3/19; Hyde Park, NY: New City Press 2003). 121-150 (ed. B. Ramsey) (WSA; Hyde Park, NY: New City Press 2004).

\section{Studies}

Bardy, G., Święty Augustyn. Człowiek i dzieło (trans. Z. Kobylańska) (Warszawa: PAX 1995).

Berlinger, R., "Zeit und Zeitlichkeit bei Aurelius Augustinus," Zeitschrift für philosophische Forschung 7 (1953) 493-510.

la Bonnardière, A.-M., "Linitiation biblique d'Augustin," Saint Augustin et la Bible (ed. A.-M. la Bonnardière) (Paris: Beauchesne 1986) 27-47.

Boros, L., "Les catégories de la temporalité chez saint Augustin," Archiv für Philosophie 21 (1958) 323-358.

Chaix-Ruy, J., "«La Cité de Dieu» et la structure du temps chez saint Augustin," Augustinus Magister. II. Communications. Congrés international augustinien, Paris 21-24 septembre 1954 (Paris: Études Augustiniennes 1955) 923-931.

Corsato, C., Biblia w interpretacji Ojców Kościoła (trans. K. Kubis) (Kraków: Bratni Zew 2007). 
Czyżewski, B., “"Być miłosiernym jak Ojciec» (Łk 6,36) w interpretacji patrystycznej”, Miłosierdzie a sprawiedliwość (ed. A. Wańka) (Studia i Rozprawy 47, Szczecin: Wydawnictwo Naukowe Uniwersytetu Szczecińskiego 2017) 57-87.

Duchrow, U., "Der sogenannte psychologische Zeitbegriff Augustins im Verhältnis zur physikalischen und geschichtlichen Zeit," Zeitschrift für Theologie und Kirche 63 (1966) 267-288.

Edling, J., "Czas i historia epifanem Boga w ujęciu św. Augustyna," Warszawskie Studia Teologiczne 9 (1996) 75-95.

Edling, J., "Rewelatywno-temporalny wymiar Odkupienia w oparciu o «De civitate Dei» św. Augustyna," Vox Patrum 32-33 (1997) 233-249.

Guitton, J., Le temps et léternité chez Plotin et saint Augustin (Paris: Boivin 1933).

Hubaux, J., "Saint Augustin et la crise cyclique," Augustinus Magister. II. Communications. Congrés international augustinien, Paris 21-24 septembre 1954 (Paris: Études Augustiniennes 1955) 943-950.

Janich, P., “Augustine Zeitparadox und seine Frage nach dem Standard der Zeitmessung," Archiv für Geschichte der Philosophie 54 (1972) 168-186.

Kaiser, H.J., Augustinus. Zeit und «Memoria» (Bonn: Bouvier 1969).

Lampey, E., Das Zeitproblem nach Bekenntnissen Augustins (Regensburg: Habell 1960).

Lancel, S., Saint Augustin (Paris: Fayard 1999).

Lechner, O., Idee und Zeit in der Metaphysik Augustinus (München: Pustet 1964).

Marrou, J.H., L'ambivalence du temps de l'histoire chez saint Augustin (Montreal - Paris: Institut d’Études Médiévales 1950).

Mejzner, M., "Miłosierdzie i/a sprawiedliwość Boga w pierwszych wiekach chrześcijaństwa," Collectanea Theologica 82/3 (2012) 41-64.

Quinn, J.M., “The Concept of Time in St. Augustine," Augustinianum 5 (1965) 5-57.

Rondeau, M.-J., Les Commentaires patristiques du Psautier (IIIe-Ve siècles). II. Exégèse prosopologique et théologie (Orientalia Christiana Analecta 220; Roma: Pontificium Institutum Orientalium Studiorum 1985).

Rondet, H., "Essais sur la chronologie des Enarrationes in psalmos de saint Augustin”, Bulletin de littérature ecclésiastique 61 (1960) 111-127, 258-286.

Rondet, H., "Essais sur la chronologie des Enarrationes in psalmos de saint Augustin (suite)," Bulletin de littérature ecclésiastique 65 (1964) 110-136.

Sawicka, J., "Symbolika lunarna w średniowiecznej poezji liturgicznej," Pamiętnik Literacki 93/3 (2002) 5-35.

Schmidt, E.A., Zeit und Geschichte bei Augustin (Heidelberg: Winter 1985).

Simonetti, M., Między dosłownością a alegorią (trans. T. Skibiński) (Kraków: WAM 2000).

Tupaj, S., "Miłosierdzie Boże i miłosierdzie chrześcijanina w «Enarrationes in Psalmos» św. Augustyna," Modlitwa i miłosierdzie w «Enarrationes in Psalmos» św. Augustyna (Studia Antiquitatis Christianae. Series Nova 5; Katowice: Księgarnia św. Jacka 2007) 111-206.

Weinand, J., Augustinus erkenntniskritische Theorie der Zeit und der Gegenwart (Universitäts-Archiv 33; München: Helios 1929).

Wielgus, S., Badania nad Biblia w starożytności i w średniowieczu (Lublin: Towarzystwo Naukowe KUL 1990).

Wilmart, A., "La tradition des grandes ouvrages de saint Augustin," Miscellanea Agostiniana (Roma: Tipografia Poliglotta Vaticana 1931) II, 257-315. 
BOGDAN CZYŻEWSKI

Zarb, S.M., Chronologia Enarrationum S. Augustini in Psalmos (Valetta: St Dominic's Priory 1948). Zgraja, B., "Symbolika księżyca w «Enarrationes in Psalmos» św. Augustyna," Vox Patrum 69 (2018) 735-753. 